\title{
A study in contrasts: two extensive Neotropical radiations
}

\author{
Bruce D. Patterson ${ }^{1 *}$ and Nathan S. Upham ${ }^{2}$ \\ 1 Integrative Research Center, Field Museum of Natural History, Chicago, IL, USA \\ 2 Department of Biology, McMaster University, Hamilton, ON, Canada \\ *Correspondence: bpatterson@fieldmuseum.org
}

Edited by:

Guillermo Orti, The George Washington University, USA

Reviewed by:

Federico Guillermo Hoffmann, Mississippi State University, USA

Keywords: Neotropical Region, Sigmodontinae, Caviomorpha, monophyly, historical biogeography, adaptive radiation, Greater Antilles, Cricetidae

\section{A commentary on}

Rodent diversity in South America: transitioning into the genomics era

by Lessa, E. P., Cook, J. A., D'Elía, G., and Opazo, J. C. (2014). Front. Ecol. Evol. 2:39. doi: 10.3389/fevo.2014.00039

Lessa et al. (2014) make a compelling case for systematic exploration of genomes in the diverse South American rodent fauna. Not only do the caviomorph and sigmodontine rodents comprise a sizable portion of the continental fauna, but they have radiated into virtually all available habitats and have adopted practically all of the life modes exploited by rodents elsewhere. Both are diverse and demonstrably monophyletic, offering great insights into the evolutionary transitions underlying these presumably adaptive radiations. Here we comment on the non-South American portions of these radiations, as well as the broader phylogenetic context of these rodents, recent work on Caribbean taxa, and historical biogeography.

Although both rodent radiations flourished in South America, neither is confined there, as clearly noted by the authors. Both groups extend far into North America, reaching the Arctic Ocean in the case of the caviomorph Erethizon and the central Great Plains in the cases of the sigmodontines Sigmodon and Oryzomys (IUCN, 2014), although only these three genera range north of Mexico (see Caviomorpha distribution in Figure 1). Both also underwent important, endemic radiations in the Caribbean, mainly on the Greater Antilles (Dávalos and Turvey, 2012). The Caribbean region constitutes one of three principal regions of endemism

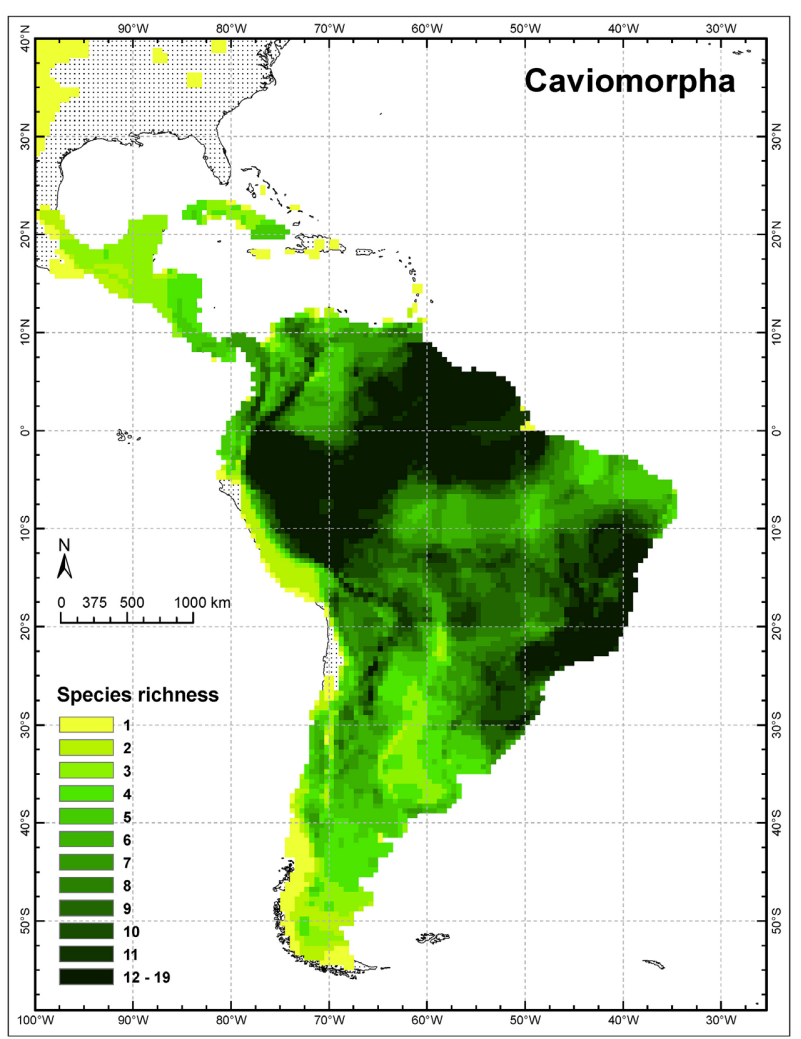

FIGURE 1 | Species richness of caviomorph rodents in the New World tropics (modified from Upham and Patterson, in press).

for the entire Neotropical Region and has been an important evolutionary theater (Morrone, 2014). Antillean caviomorphs, which are all endemic, included 9 genera of hutias (Capromyidae) and 6 genera of giant hutias (Heptaxodontidae and incertae sedis), totaling 45 species, 31 of them now extinct. Antillean sigmodontines included 4 genera (2 of which were endemic) and perhaps 18 species of rice rats, all now extinct. Of course, the extent of Quaternary and human-caused extinctions complicates attempts to document the genetics and ecology of these radiations (see also Morgan and Woods, 1986). Nevertheless, genomic tools offer greater insights into phylogenies than were available via Sanger sequencing (McCormack et al., 2013). A recent analysis using target enrichment and nextgeneration sequencing of mitochondrial and nuclear genes greatly clarified the phylogeny and historical biogeography of capromyids (Fabre et al., 2014). Hutias are 
confidently recovered as a subclade of the largely South American Echimyidae, and sister to forms from eastern Brazil (see also Upham and Patterson, in press). This case highlights the importance of studying monophyletic groups, and not geographic partitions of them, in any evolutionary analysis. The utility of next-generation sequencing for dried tissue "museomics" also opens the door for studying such rare or recently extinct taxa in a genetic context (Rowe et al., 2011).

The groups in question belong to two of the three major lineages of Rodentia (Blanga-Kanfi et al., 2009; Fabre et al., 2012). Caviomorphs represent the largest group of Ctenohystrica, and the only one found in the Western Hemisphere; they are sister to the African Phiomorpha (Honeycutt, 2009). Sigmodontines constitute the second-largest group of the "mouse-related" clade, a New World counterpart to the explosive murine radiation that took place in the Eastern Hemisphere. Caviomorph rodents colonized South America an estimated $42 \mathrm{Mya}$, in the midst of its extended Cenozoic isolation (Rowe et al., 2010; Upham and Patterson, in press), and began diversifying in the Oligocene. At this time, South America lacked other rodents (including squirrels, gophers, beavers, voles, and muskrats), as well as deer and other extant ungulates. This ecological impoverishment prompted a remarkable Cenozoic radiation, including truly giant herbivores (Rinderknecht and Blanco, 2008) and many dozens of extinct lineages (Pérez and Pol, 2012). At least for the Octodontoidea, the most speciose superfamily of caviomorph, this radiation was rooted in the Southern Andes and Patagonia and unfolded south-to-north (Upham and Patterson, 2012). On the other hand, the sigmodontines are sister to the Central American tylomyinestheir divergence began in the mid-to-late Miocene (9-12 Mya), and they colonized South American landscapes northto-south, as a leading element of the Great American Biotic Interchange that also brought squirrels, pocket gophers and pocket mice, deer, and peccaries (Parada et al., 2013; Leite et al., 2014). These differences in historical, geographic, and ecological context pose numerous interesting questions for transcriptomic analysis.

Enrique Lessa and company have done evolutionary biologists in general, and students of Neotropical mammals in particular, a great service in identifying the status and potential value of concerted action to fill knowledge gaps regarding the genomics of these rodents. One can only hope that their call is answered, enthusiastically.

\section{REFERENCES}

Blanga-Kanfi, S., Miranda, H., Penn, O., Pupko, T., Debry, R. W., and Huchon, D. (2009). Rodent phylogeny revised: analysis of six nuclear genes from all major rodent clades. BMC Evol. Biol. 9:12. doi: 10.1186/1471-2148-9-71

Dávalos, L. M., and Turvey, S. T. (2012). "West Indian mammals: the old, the new, and the recently extinct," in Bones, Clones, and Biomes: the History and Geography of Recent Neotropical Mammals, eds B. D. Patterson and L. P. Costa (Chicago, IL: University of Chicago Press), 157-202.

Fabre, P. H., Hautier, L., Dimitrov, D., and Douzery, E. J. P. (2012). A glimpse on the pattern of rodent diversification: a phylogenetic approach. BMC Evol. Biol. 12:88. doi: 10.1186/14712148-12-88

Fabre, P.-H., Vilstrup, J. T., Raghavan, M., Sarkissian, C. D., Willerslev, E., Douzery, E. J. P., et al. (2014). Rodents of the Caribbean: origin and diversification of hutias unravelled by nextgeneration museomics. Biol. Lett. 10, 20140266. doi: $10.1098 / \mathrm{rsbl} .2014 .0266$

Honeycutt, R. L. (2009). "Rodents (Rodentia)," in The Timetree of Life, eds S. B. Hedges and S. Kumar (Oxford: Oxford University Press), 490-494.

IUCN. (2014). Red List of Threatened Species. Version 2014.1. (Accessed 6 July, 2014).

Leite, R. N., Kolokotronis, S.-O., Almeida, F. C., Werneck, F. P., Rogers, D. S., and Weksler, M. (2014). In the wake of invasion: tracing the historical biogeography of the South American cricetid radiation (Rodentia, Sigmodontinae). PLoS ONE 9:e100687. doi: 10.1371/journal.pone.01 00687

Lessa, E. P., Cook, J. A., D’Elía, G., and Opazo, J. C. (2014). Rodent diversity in South America: transitioning into the genomics era. Front. Ecol. Evol. 2:39. doi: 10.3389/fevo.2014.00039

McCormack, J. E., Hird, S. M., Zellmer, A. J., Carstens, B. C., and Brumfield, R. T. (2013). Applications of next-generation sequencing to phylogeography and phylogenetics. Mol. Phylogenet. Evol. 66, 526-538. doi: 10.1016/j.ympev.2011. 12.007

Morgan, G. S., and Woods, C. A. (1986). "Extinction and the zoogeography of West Indian land mammals," in Island Biogeography of Mammals, eds L. R. Heaney and B. D. Patterson (London: Academic Press and the Linnean Society of London), 167-203.
Morrone, J. J. (2014). Biogeographical regionalisation of the Neotropical region. Zootaxa 3782, 1-110. doi: 10.11646/zootaxa.3782.1.1

Parada, A., Pardinas, U. F. J., Salazar-Bravo, J., D’Elía, G., and Eduardo Palma, R. (2013). Dating an impressive Neotropical radiation: molecular time estimates for the Sigmodontinae (Rodentia) provide insights into its historical biogeography. Mol. Phylogenet. Evol. 66, 960-968. doi: 10.1016/j.ympev.2012.12.001

Pérez, M. E., and Pol, D. (2012). Major radiations in the evolution of caviid rodents: reconciling fossils, ghost lineages, and relaxed molecular clocks. PLOS ONE 7:e48380. doi: 10.1016/j.ympev.2012. 12.001

Rinderknecht, A., and Blanco, R. E. (2008). The largest fossil rodent. Proc. R. Soc. B 275, 923-928. doi: 10.1098/rspb.2007.1645

Rowe, D. L., Dunn, K. A., Adkins, R. M., and Honeycutt, R. L. (2010). Molecular clocks keep dispersal hypotheses afloat: evidence for trans-Atlantic rafting by rodents. J. Biogeogr. 37, 305-324. doi: 10.1111/j.1365-2699.2009. 02190.x

Rowe, K. C., Singhal, S., Macmanes, M. D., Ayroles, J. F., Morelli, T. L., Rubidge, E. M., et al. (2011). Museum genomics: low-cost and high-accuracy genetic data from historical specimens. Mol. Ecol. Resour. 11, 1082-1092. doi: 10.1111/j.17550998.2011.03052.x

Upham, N. S., and Patterson, B. D. (2012). Diversification and biogeography of the Neotropical caviomorph lineage Octodontoidea (Rodentia: Hystricognathi). Mol. Phylogenet. Evol. 63, 417-429. doi: 10.1016/j.ympev.2012. 01.020

Upham, N. S., and Patterson, B. D. (in press). "Phylogeny and evolution of caviomorph rodents: a complete timetree of living genera," in Biology of Caviomorph Rodents: Diversity and Evolution, eds A. I. Vassallo and D. Antenucci (Buenos Aires: SAREM).

Conflict of Interest Statement: The authors declare that the research was conducted in the absence of any commercial or financial relationships that could be construed as a potential conflict of interest.

Received: 07 July 2014; paper pending published: 15 July 2014; accepted: 17 July 2014; published online: 05 August 2014.

Citation: Patterson BD and Upham NS (2014) A study in contrasts: two extensive Neotropical radiations. Front. Ecol. Evol. 2:44. doi: 10.3389/fevo.2014.00044

This article was submitted to Phylogenetics, Phylogenomics, and Systematics, a section of the journal Frontiers in Ecology and Evolution.

Copyright (C) 2014 Patterson and Upham. This is an open-access article distributed under the terms of the Creative Commons Attribution License (CC BY). The use, distribution or reproduction in other forums is permitted, provided the original author(s) or licensor are credited and that the original publication in this journal is cited, in accordance with accepted academic practice. No use, distribution or reproduction is permitted which does not comply with these terms. 